\title{
The effect of mechanical treatment on the cannabinoid content of hemp samples
}

\author{
Laura CZERŐDINÉ KEMPF ${ }^{1,2}$ - Zuzana FINTA² - Márton JOLÁNKAI ${ }^{1}$ - \\ Ákos TARNAWA ${ }^{1}$ \\ 1: Institute of Crop Production, Szent István University, 2100 Gödöllő, Páter K. u. 1.; \\ E-mail: Kempf.Lauraaa@gmail.com \\ 2: Agromag Kft., 3356 Kompolt, Fleischman u. 4.
}

Keywords: industrial hemp, cannabinoids, CBD, THC, mechanical treatment

\section{Introduction}

Hemp (Cannabis sativa L.) is a traditional and important raw material for the textile industry (Ranalli \& Venturi 2004) and is currently of interest as a therapeutic agent of medical products (Clark \& Pate 1994) thanks to the valuable natural compounds, the cannabinoids (Clarke \& Watson 2007; Parmar et al. 2016). Cannabinoid synthesis and cumulation is different in leaves from various plant parts (Bócsa et al. 1997). Cannabinoids are concentrated in the secretory cavity (Kim \& Mahlberg 2003) and abundant in glands isolated from bracts or leaves of pistillate plants (Hammond \& Mahlberg, 1977; Kassai 1994; Mahlberg \& Kim, 2004).

\section{Materials and methods}

An EU listed variety was used. In the followings the samples are signed with numbers 1-4. The THC content of the varieties should be measured according to the standardised test $(162 / 2003$. (X. 16.) Krm. r.) and its content in sample should not exceed the limit of $0.2 \%$. As the accumulation of any kind of cannabinoids is not homogeneous in plant tissues, either in stages of the vegetation; the unfertilized female plants were sampled with hypothesis of determination of higher cannabinoid content. The flower samples were first manually smashed and grinded afterwards. In consequence of grinding several fractions of sample appeared. The upper fraction of powder was measured separately, before mixing it with the other fractions. The testing of three fractions "smashed", "powder" and "grinded" was repeated four times with GC. The recorded results were evaluated by MS Excel software package.

\section{Results and discussion}

In our experiment we gained the following results (Table 1). For better understanding, it is shown on a diagram (Figure 1 and 2).

Table 1: THC and CBD content (\%) in the measured samples

\begin{tabular}{|l|l|l|l|l|l|l|l|l|}
\hline \multirow{2}{*}{} & \multicolumn{2}{|c|}{ sample 1 } & \multicolumn{2}{c|}{ sample 2 } & \multicolumn{2}{c|}{ sample 3 } & \multicolumn{2}{c|}{ sample 4 } \\
\cline { 2 - 9 } & THC \% & CBD \% & THC \% & CBD \% & THC \% & CBD \% & THC \% & CBD \% \\
\hline smashed & 0.407 & 1.199 & 0.576 & 1.646 & 0.198 & 0.576 & 0.068 & 0.195 \\
\hline grinded & 0.385 & 1.134 & 0.395 & 1.128 & 0.095 & 0.280 & 0.056 & 0.161 \\
\hline powder & 0.893 & 2.628 & 1.631 & 4.753 & 0.434 & 1.264 & 0.255 & 0.735 \\
\hline
\end{tabular}




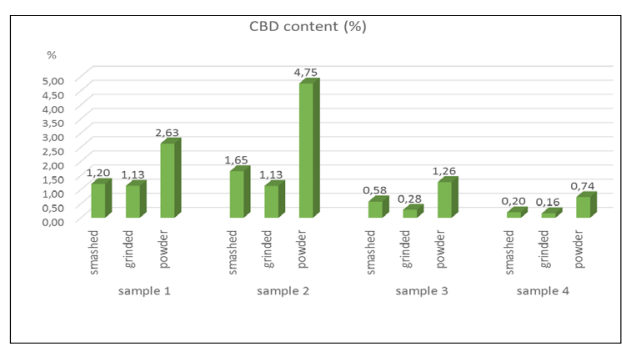

Figure 1: CBD content (\%) in the measured samples

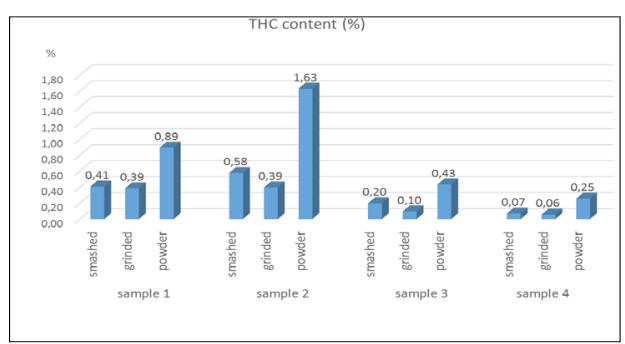

Figure 2: THC content (\%) in the measured samples

\section{Conclusions}

Big differences in measured values can be observed between samples belonging to the different plants as well as between powder fraction and the two remaining ones. So called powder fraction (supposedly consisted of epidermal glands) contains much more of each cannabinoid. This method can provide a simple physical purification of natural cannabinoids from the plant tissues. After the fractions are mixed together, it makes no difference comparing to the ,smashed" one, respectively decreasing tendency can be observed. Results of this study can suggest, that GC method has low, or even non sensitivity to the size of particles in samples. The decreasing tendency can be the consequence of measuring in the powder as well.

\section{Acknowledgement}

This publication is created in number EFOP-3.6.1-16-2016-0016, the specialise of the SZIU Campus of Szarvas research and training profile with intelligent specialization in the themes of water management, hydroculture, precision mechanical engineering, alternative crop production.

\section{References}

Bócsa, I., Máthé, P., \& Hangyel, L. (1997): Effect of nitrogen on tetrahydrocannabinol (THC) content in hemp (Cannabis sativa L.) leaves at different positions. J Int Hemp Assoc, 4, 80-81.

Clark, R. C., \& Pate, D. W. (1994): Medical marijuana. Hemp today. Oakland: Quick American Archives, 303309.

Clarke, R. C., \& Watson, D. P. (2007): Cannabis and natural cannabis medicines. In Marijuana and the cannabinoids (pp. 1-15). Humana Press.

Hammond, C. T. and Mahlberg, P. G. (1977): Morphogenesis of capitate glandular hairs of Cannabis sativa (Cannabaceae). American Journal of Botany, 64: 1023-1031. doi:10.1002/j.1537-2197.1977.tb11948.x

Kassai M.K. (1994): Production of leguminous crops in Hungary. Grain Legumes Paris. 5. 24-25 pp.

Kim, E. S., and Mahlberg, P. G. (2003): Secretory vesicle formation in the secretory cavity of glandular trichomes of Cannabis sativa L.(Cannabaceae). Molecules and Cells, 15(3), 387-395.

Mahlberg, P. G. and Kim, E. S. (2004): Accumulation of cannabinoids in glandular trichomes of Cannabis (Cannabaceae), Journal of Industrial Hemp, 9:1, 15-36, DOI: 10.1300/J237v09n01_04

Parmar, J. R., Forrest, B. D., \& Freeman, R. A. (2016): Medical marijuana patient counseling points for health care professionals based on trends in the medical uses, efficacy, and adverse effects of cannabis-based pharmaceutical drugs. Research in Social and Administrative Pharmacy, 12(4), 638-654.

Ranalli, P., \& Venturi, G. (2004): Hemp as a raw material for industrial applications. Euphytica, 140(1-2), 1-6.

162/2003. (X. 16.) Korm. rendelet (19.12.2018.): http://ndi-szip.hu/Controls/DownloadEDoc.aspx?attId=367ca 1a9-d98c-478e-8706-c006a9dff811 